\title{
ETIKA DAN MORAL BISNIS ISLAM DALAM PENINGKATANPERFORMA PERUSAHAAN
}

\author{
Yayu Andini \\ Universitar Brawijaya
}

\begin{abstract}
In carrying out good development, Good Human Resources be one key to success. Today, the view of the improvement of human resources by many experts. Apart from the existing management ethics, to be one important factor enhancement of human resources. business ethics today began to be highlighted as part of the implementation of economic activity. Every business entity anywhere, doing things in improving the quality of the resources at their disposal. In the study of business ethics of Islam, in improving the performance of the company ethics and morals of Islam need to reiterate. Where in doing business shari'ah, not only profit but also to the benefit gained, or in other words the usefulness for each other. Islam upholds humanity so there are many verses that govern how where habluminanas or social life run as his creatures.
\end{abstract}

Keywords: Business Ethics and Islam, Performance Company, Al-Quran and Al-Hadith

\section{ETIKA DAN MORAL BISNIS ISLAM DALAM PENINGKATANPERFORMA PERUSAHAAN}

\begin{abstract}
Abstrak
Dalam melaksanakan pembangunan yang baik, Sumber daya Manusia yang kompenten menjadi salah satu kunci keberhasilannya. Dewasa ini, pandangan mengenai peningkatan sumber daya manusia banyak di sumbarkan oleh para ahli. Lepas dari manajemen yang telah ada nilai etika, menjadi salah satu factor penting peningkatan sumber daya manusia.etika bisnis dewasa ini mulai disoroti sebagai bagian dalam pelaksanaan aktivitas ekonomi. Setiap entitas bisnis mana pun, melakukan berbagai hal dalam peningkatan kualitas sumber daya yang mereka miliki. Dalam kajian etika bisnis islam, dalam peningkatan performa perusahaan etika dan moral islam perlu di tegaskan. Dimana dalam menjalankan bisnis secara syari, tidak hanya laba yang diraih namun juga kemaslahatan atau dalam kata lain kebermanfaatan bagi sesam. Islam sangat menjunjung tinggi prikemanusaan sehingga terdapat banyak ayat yang mengatur bagai mana habluminanas atau kehidupan bermasyarakat dijalankan sebagai makhluk ciptaanNya.
\end{abstract}

Kata kunci: Etika dan Bisnis Islam, Performa Perusahaan, Al-Quran dan Al-Hadist 


\section{Pendahuluan}

Dalam menuju pembangunan yang lebih baik, sumber daya manusia yang unggul menjadi salah satu faktor penentunya. Banyak pandangan para ahli mengatakan bahwa dengan adanya SDM yang unggul dapat menajadi salah satu keunggulan kompetitif berkelanjutan yang di harapkan dapat membawa dampak signifikan bagi Pembangunan Nasional. Penciptaan SDM yang Unggul menyoroti beberapa hal mendasar lebih dari ekonomi dan teknologi ; mencakup spiritual, sosial dan dimensi politik.

Dalam era globalisasi ini, dimana kapitalisme membuktikan kelebihannya di bandingkan sosialisme tetap tidak mampu membuat sauatu kegiatan ekonomi yang sepenuhnya lepas dari kegagalan pasar. Kenyataan ini bahkan menimbulkan dampak negative lain khususnya bagi Negara dunia ketiga yang cenderung dijadikan sebagai objek dibandingkan subjek dari kapitalis (Hamam:20). Secara singkat aktivitas ekonomi akan terjadi ketika ada transaksi yang terjadi antar dua orang atau lebih. Semakin banyak aktivitas yang terjadi akan memperluar wilayah serta orang yang terlibat dalam aktivitas tersebut. Sehingga ketika salah satu aktivitas tersebut berhenti atau mengalami kegagalan sedikit banyak akan berdampak pada aktivitas lainnya. Karena aktivitas tersebut merupakan tindakan manusia, sebenarnya kegagalan tersebut juga dapat dikarenakan kegagalan individu individu tersebut dalam menjalankannya.

Dewasa ini pandangan mengenai etika bisnis di dunia tidak begitu dianggap sebagai faktor dalam perjalanan suatu bisnis. Mereka para pemegang ekonomi klasik mengangap adanya etika bisnis hanya akan mengganggu keilmiahan dari ilmu ekonomi itu sendiri. Keilmiahan tersebut melibatkan anggapan adanya ketidak objektivan dalam memandang sebuah persoalan ekonomi ketika aktivitas tersebut dikaitkan dengan etika ekonomi baik secara makro maupun mikro. Namun, gejolak perekonomian yang menjurus pada jurang kehancuran, membuka mata para ilmuan akan pentingnya etika bisnis dalam ilmu ekonomi beserta aktivitas di dalamnya. Ketidak adaan etika tersebut malah memunculkan kegagalan suatu system ekonomi itu sendiri. Seperti munculnya opnum opnum korupsi, nepotisme dan kolusi.

Dimensi pembangunan juga berfokus pada peningkatan kesejahteraan individu dan peran aktif mereka dalam usaha pengembangan diri untuk memperoleh pengetahuan. Oleh karena itu, setiap individu harus memiliki kecerdasan IQ yang baik serta emosional yang setabil.Menurut Chowdhury, seorang individu dikatakan produktif ketika dapat mengakusisi kualitas dan keterampilan yang diperlukan baik melalui pendidikan ataupun pelatihan lainnya, sehingga ia dapat berguna bagi masyarakat secara keseluruhan dan dirinya khususnya (Golam: 2012).Menurut Khasali (2005 suatu organisasi dapat bertahan panjang bukan dibentuk oleh manajemen yang hebat, tidak juga oleh orang-orang yang hebat, ataupun sistem, melainkan dibangun oleh kekuatan nilai-nilai (values).

Dikutip dari Agustianto 2008, pada tahun 1990-an Paul Ormerof, menerbitkan buku mengenai "The Death of Ekonomi". Makin tipisnya kesadaran moral dalam kehidupan ekonomi dan bisnis modern malah membawa dampak kehancuran di suatu wilayah perekonomian. Sehingga lanjutnya, perbincangan mengenai etika bisnis dewasa ini mulai disoroti sebagai bagian dalam pelaksanaan aktivitas ekonomi. Adanya tanggung jawab sosial oleh para kapitalis, cara pandang pelaku usaha, politik dan teknologi termasuk di dalam wacana bisnis tersebut. Berhubungan dengan tanggug jawab sosial, dapat di cerminkan dari adanya suatu kesejahteraan yang merupakan dampak dari suatu kegiatan ekonomi dengan sekala tertentu. Misalnya, pabrik dengan banyak 
pekerja memberikan nilai gaji yang sepadan atas output yang dihasilkan oleh para pekerja. Sehingga nantinya pekerja akan mengkonsumsi sesuai dengan apa yang telah ia hasilkan.

Nilai nilai etik yang terkandung dalam setiap agama, diharapkan akan menjadi pedoman bagi setiap insan untuk mencapai kemakmuran dan kesejahteraan individu. Agama mengajarkan nilai nilai seperti integritas, kejuujuran, kedisiplinan dan hal hal yang menyangkut etos kerja yang diperlukan dalam pembangunan SDM yang professional dalam meningkatkan performa perusahaan.Dalam paradigm spiritual, potensi manusia untuk berkinerja harus menjadikan hidup lebih positif dan produksif untuk mencapai prestasi kerja yang religious. Sebagai seorang muslim, menyelaraskan segala tindak tanduk dan tingkah laku merupakan hal yang mutlak dan telah digambarkan dalam pedoman hidup Al- Quran Nur Karim.

Indonesia, yang mayoritas merupakan pemeluk agama muslim. Seharusnya memiliki potensi yang luar biasa dalam mengembangkan etika islam dan kinerja yang nantinya mengarah pada produktivitasdan performa bisnis. Potensi masyarakat muslim yang menjadi sumber daya manusia unggulan tentunya diharapkan akan berguna dalam pembangunan. Nilai nilai agama yang diaplikasikan oleh individu maupun perusahaan dapat membawa dampak terhadap perfotrma perusahaan dan juga kebajikan hidup sebagai manusia.

\section{Tinjauan Pustaka}

\section{Pengertian Etika}

Kata etika (ethics) secara etimologis berasal dari bahasa yunani, ethos, yang berarti karakter (McLeod \& Schell, 2004). Jika dalam bahasa yang mudah, etika dapat dikatakan sebagai falsafah moral yang merupakan pedoman dalam bertingkah laku baik dari sudut pandang social budaya dan agama. Etika juga mengarah pada hal yang mengandung nilai apa yang boleh dan apa yang tidak boleh secara normative. Barney (dalam arijo) mengungkapkan : etika adalah study yang bersifat normative sebab etika menjelaskan apa yang seharusnya dilakukan seseorang dan apa yang seharusnya tidak dilakukan seseorang.

Menurut hamam 2014. Etika adalah ilmu yang menjelaskan arti yang baik dan buruk, menerangkan apa yang seharsnya dilakukan oleh manusia kepada oranglain, menyatakan tujuan yang harus dicapai manusia dalam perbuatannya dan menunjukan jalan untuk melakukan apa yang seharusnya di perbuat.

Dalam kajian keilmuan, etika merupakan suatu cabang filsafat yang mempelajari dadar dari nilai yang bersifat normative "baik" atau "buruk". Namun, perlu di perhatikan terkadang etika tidak sama dengan moral. Dimana moral merupakan suatu adat yang telah ada di masyarakat yang diharapkan akan diikuti dengan kesadaran dari setiap anggota yang terdapat didalamnya. Sedang etika merupakan ukuran standar kepercayaan atau pemikiran yang mengisi suatu individu dalam suatu kelompok masyarakat (arijo).

Griffin dan ebert (dalam arijo:) mengungkapkan prilaku etis sebagai prilaku yang sesuai dengan norma- norma social yang diterima secara umum sehubungan dengan tindakan tindakan yang bermanfaat. Sedangkan prilaku sendiri merupakan sifat dan karakteristik dari setiap individu dalam menyesuaikan diri atau beradaptasi dengan lingkungannya,yang meliputi: sifat, kemampuan, nilai, keterampilan, intelegesi dalam menerima informasi sekitar dan hal yang berkaitan dengan disiplin individu.

Dari pemaparan tersebut penulis
menarik pandangan bahwa etika


merupakan seperangkat nilai baik itu positive ataupun negatik dalam berinteraksi satu sama lain. Etika disini lebih mengarah pada bagaimana seharusnya manusia dapat memunculkan manfaat dari kegiatannya baik untuk dirinya dan orang lain yang ada di sekitarnya.

\section{Etika Islam}

Dalam mendisiplinkan prilaku individu terhadap lingkungan sekitarnya, islam telah membuat suatu nilai tersendiri sebagai pedoman hidup bermasyarakat. Berlandaskan pada Al Quran dan Al Hadist, setiap muslim diwajibkan untuk memahami bagai mana batasan atau nilai dalam bertindak dalam islam, baik pada sesame individu, dirinya, kelompok tertentu dan bahkan dalam memanfaatkan sumber daya alam yang terbatas. Hal ini tentunya bermaksud untuk mengkontrol kehidupan agar mampu seimbang dan bijaksana.

\section{Etika Bisnis dalam Islam}

Dalam alur sejarah, seluruh umat muslim di dunia telah mengetahui bagi mana jalan hidup Rassullullah Muhammad SAW sebagai seorang pedagang yang sangat menjungjung nilai nilai kejujuran hingga ia pun menjaadi salah satu pedagang kaya pada masanya. Hal ini dibuktikan dengan mahar yang ia berikan kepada Siti Khadijah berupa puluhan ekor unta merah yang juga merupakan kendaraan termewah pada masa itu, jika kita konfersikan hasilnya bias ratusan juta rupiah pada saat ini. Nilai kejujuran ini juga ditanamkan dalam Al Hadist " tetapkanlah kejujuran karena sesungguhnya kejujuran mengantarkan kepada kebaikan dan sesungguhnya kebaikan mengantarkan kepada surga".

Dalam pandangan islam bisnis merupakan aspek kehidupan yang dikelompokan kedalam masalah muamalah, yakni muamalah yang berkenaan dengan hubungan yang bersifat horizontal dalam kehidupan manusia.
Selain itu, bisnis dalam islam juga erat kaitannya dengan sektir rill dimana transaksi bisnis itu dilakukan antar individu. Hingga islam juga mengatakan pertumbuhan ekonomi bukan ukuran utama dari pencapaian ekonomi itu sendiri melainkan kesejahteraan masyarakat dan pemerataan.Sehingga etika bisnis secara singkat merupakan suatu nilai baik atau salah yang seharusnya dilaksanakan oleh individu dalam menjalankan aktivitas pertukarannya atau pun ekonomi.

Sesungguhnya, poinpenting dalam menjalankan bisnis dalam islam adalah pelakunya sebagai produsen. Seorang pebisnis muslim juga wajib menerapkan etika islam yang mencakup Husnul Khuluq. Dimana dengan memegang teguh prinsip dan etika islam, Allah SWT akan melapangkan hatinya, dan membukakan pintu rejekinya, karena orang yang memegang teguh prinsip ini tentunya mengetahui bagai mana ia harus bertindak sebagai seorang muslim terhadap sesame manusia. Artinya aka nada kesejahteraan yang terlaksana dengan setap individu yang memegang etika islam terhadap masyarakat di sekelilingnya.

Dalam kajian yang dilakukan oleh Ruslan Abd. Ghofur mengenai managemen SDM dalam perspektif Ekonomi Syariah dengan mengambil study kasuk pada Lembaga Keuangan Publik Islam terdapat beberapa poin penting mengenai keterkaitan etika bisnis islam dan prilaku terhadap kinerja lembaga keuangan tersebut, antara lain: 1) sumber daya manusia dalam ekonomi syariah mempunyai posisi yang penting bukan hanya sebagai objek dalam pemetaan managemen lembaga keuangan tersebut, namun juga sebagai objek dalam ujung tombak manageman perusahaan untuk mampu meningkatkan kinerjanya. 2) peningkatan profesionalisme SDM yang tidak hanya dilaksanakan dalam koteks peningkatan produktifitas namun juga dalam taraf pemerataan kesejahteraan. 3) adanya manageman syariah tersbeut juga 
mengarahkan setiap individu untuk mampu bekerja sebaik mungkin dan di barengi dengan stabilitas rohaniah manusia dalam mendekatkan diri pada Allah SWT.Qardawi dalam Syafrudin dan Efa menyatakan dalam bukunya, norma dan etika ekonomi islam menyampaikan pemisahan anatar nilai dan prilaku dalam bisnis secara syari sebagai berikut:

1. Larangan memperdagangkan barang atau jasa haram. Sesuatu yang haram menurut Al-quran ataupun Al- Hadist sudah tentu hanya akan menimbulkan hal negative bagi penggunanya, hal tersebut juga hanya akan membawa sipengguna maupun sipenjual berada dalam lingkaran kemaksiatan.

2. Bersikap benar, amanah dan jujur, adalah kunci keberhasilan yang di bawa oleh nabi Muhammad SAW yang senantiasa membuat para pelangannya mempercayai beliau sebagai seorang pedagang yang juga berdampak pada hasil pencapaiannya.

3. Menegakkan keadilan dan mengharamkan bunga atau riba. Riba secara singkat merupakan hasil yang didapat tanpa melakukan pengorbanan apapun, islam sangat menjunjung tinggi nilai etos kerja sehingga islam memandang riba sebagai hasil yang tidak layak diterima tanpa jerih payah apapun.

4. Menerapkan kasih sayang dan mengharamkan monopoli. Dalam ilmu ekonomi klasik, tindakan monopoli merupakan tindakan yang dapat menimbulkan kegagalan pasar yang bahkan terkadang adanya tindakan monopoli membuat kesejahteraan tidak terlaksanakan dengan baik. Islam memandang monopoli sebagai sesuatu yang harus dihindarkan demi kemaslahatan bersama. Meskipun, dalam beberapa poin masih mentolelir adanya monopoli. Seperti ketika hal tersebut berhubungan dengan kebutuhan khalayak ramai yang senantiasa berkaitan dengan hajat hidup orang banyak.

5. Menegakkan toleransi dan persaudaraan.

6. Berpegangan pada prinsip bahwa perdagangan merupakan bekal menuju akhirat. Dalam dunia yang sesaat ini, prilaku ataupun tindakan manusia akan mengarah pada kebermanfaatan terhadap sesame dan kemaslahatan pribadi untuk mencapai jannahnya. Sehingga berdagang suatu barang ataupun jasa yang dibutuhkan masyarakat diharapkan dapat membawa dampak positive terhadap sipenjuan sebagai peraih laba dan si pembeli dalam memenuhi hajat hidupnya.

\section{Pembahasan}

Pada dasarnya, Islam menganut kebebasan yang merujuk pada kebebasan yang berkeadailan, sesuai dengan syariat atau undang undang agama dan beretika. Sehingga melakukan perdagangan islammempunyai nilai nilai tersendiri terhadap norma dan etika.Secara umum, prinsip-prinsip yang berlaku dalam bisnis yang baik sesungguhnya tidak dapat dilepaskan dari kehidupan kita sebagai manusia, dan prinsip-prinsip ini sangat erat terkait dengan sistem nilai yang dianut oleh masing-masing individu (Saarce). Dengan terbentuknya budaya kerja yang baik, maka diharapkan setiap program yang diterapkan dalam rangka manajemen kualitas dan biaya bukan saja dapat berjalan dengan baik tetapi juga menjadi sebuah gaya hidup dalam bekerja. Dengan demikian, program tersebut tidak hanya berhenti ketika sudah mencapai target, tapi tetap akan berjalan hingga mencapai target yang lebih tinggi lagi sesuai dengan goal perusahaan. Kode etik tersebut menuntut karyawan dan pimpinan untuk melakukan praktek etika bisnis yang terbaik di dalam semua hal 
yang dilaksanakan atas nama perusahaan. Apabila prinsip tersebut telah mengakar di dalam budaya perusahaan, maka seluruh karyawan dan pimpinan akan berusaha memahami dan mematuhi "mana yang boleh" dan "mana yang tidak boleh" dilakukan dalam aktivitas perusahaan.

Bermula dari kesadaran bahwa Alla SWT senan tiasa menyertai makhluknya dalam setiap aktifitasnya membuat manusia berfikir dalam melakukan tindakannya. Tentunya, nilai kehidupan tersebut telah ditetapkan mana yang boleh mana yang tidak boleh, mana yang baik mana yang buruk. Hal ini mengantarkan pada kinerja sumber daya manusia yang lebih baik lagi bagi perusahaan. Dengan mengacu pada integritas yang tinggi. Integritas dari kata "integrity" berarti "soundness of moral principle and character honesty." Dengan kata lain, mereka yang memiliki integritas lazimnya memiliki hati nurani yang bersih, mempunyai prinsip moral yang tangguh, adil serta jujur, dan tidak takut kepada siapapun, kecuali kepada Tuhan (Amirsyahya,

http://www.mail_archieve.com/perbendah araan-list@yahoogroups.com).

Dalam beberapa Ayat Al-Qur'an juga Al- Hadist kita dapat melihat beberapa aplikasi dan implikasi yang mampu membawa perusahaan pada tingkat performa tertentu yang jelas akan bermanfaat tidak hanya bagi perusahaan beserta karyawan di dalamnya, namun juga terhadap masyarakah secara luas. AlQur'an surat Al Ma'idah(5): ayat 58 menyebutkan "hai orang orang yang beriman jangan lah kamu haramkan yang baik yang telah Allah halalkan bagimu dan janganlah melampaui batas. Sesungguhnya Allah tidak menyukai orang orang yang melampaui batas". Seperti dalam tinjauan sebelumnya sesuatu melampoi batas atau melebihi porsinya adalah sesuatu yang Allah SWT tidak senangin dan hanya membawa dampak buruk saja, seperti adanya monopoli itu sendiri.
Selain hal tersebut, Organisasi yang kokoh tidak dibangun dari seberapa besar akumulasi modal ataupun produk yang menjadi inputnya. Dimana yang ditekankan disini adalah bagai mana sumber daya manusia dimanfaatkan sebagai sumber daya yang kompetitif dan berdaya saing tinggi agar mampu meningkatkan performa perusahaannya.perlakuan ataupun tingkah laku individu juga telah diatur dalam menjalankan kewajiban dan menerima haknya. Dalam memenuhi kebutuhan rohaninya, manusia sebagai makhluk-Nya tentunya telah diajarkan bagai mana menjalankan perintah utama dan yang disunahkan-Nya sebagai bekal ia dalam perjalanan akhirat. Dalam memenuhi kebutuhan jiwanya berupa fisik, sandang pangan dan hal lainnya, islam telah mengajarkan bagai mana manusia sebaiknya berusaha dengan cara yang halal. Seperti dalam pepatah ' beribadahlah kamu, seolah olah hari ini akan menjadi hari trakhir mu di dunia. Bekerja lah kamu seolah olah kamu akan hidup seratus bahkan seribu tahun lagi.

Dalam Al- Quran surat Al Muddatsir (74): 38 mengatakan"tiap tiap diri bertanggung jawab atas apa yang telah diperbuatnya.".hal ini mengarah pada bagai mana setiap individu menjalankan aktivitasnya khususnya dalam hal memenuhi kebutuhannya dengan bekerja untuk berlaku jujur, amanah dan Fathonah. Mengerti apa yang seharusnya diperbuat dan apa yang tidak seharunya dilakukan. Memahami mana yang banyak menimbulkan kebaikan bagi dia dan orang di sekitarnya serta memilih mana yang hanya akan menimbulkan mudharot bagi nya dan orang disekitarnya. Tindakan apa yang pantas dilakukan sebagai karyawan, tindakan apa yang sehapantasnya dilakukan oleh manajeman dalam mempertahankan dan meningkatkan kinerja para karyawannya. Seperti yang dituliskan dalam Al- Quran surat Al furkon(25): 2 yang artinya "sesungguhnya kami telah menciptakan segala sesuatu berdasarkan 
ukurannya". Dapat difahami dengan apa dan bagai mana tindakan seseorang dalam menduduki posisinya.

Selain hal yang menyangkut adanya manajemen sumber daya manusaia yang sesuai dengan syariat. Dalam menjalankan bisnis, seseorang juga perlu memperhatikan hal hal yang mendasar dalam oprasionalnya. Seperti, tujuan perusahaan disamping laba juga harus memberikan manfaat bagi setidaknya masyarakat di sekitarnya. Barang ataupun jasa yang dijual juga berupa barang dan jasa yang dapat menimbulkan kemaslahatan atau kebermanfaatan bagi sesama. Perlu digaris bawahi poin penting dalam kajian ini adalah adanya suatu konsep kemaslahatan. Dimana konsep tersebut mengarah pada dampak apa yang dapat terjadi dari tindakan individu itu sendiri ataupun dari perusahaan yang bersangkutan. Dalam AlQuran surat An-Nisa (4): 85 mengatakan "Barang siapa memberikan hasil yang baik, niscaya ia akan memperoleh bagian pahala. Dan barang siapa menimbulkan akibat yang buruk, niscaya ia akan memikul konsekuensinya.".lebih menegaskan kembali bagai mana individu ataupun perusahaan bertindak.

Dalam melihat dampak nyata adanya etika dan moral islam sebagai suatu proses dalam peningkatan performa perusahaan, pembahas akan memberikan beberapa uraian singkat terkait studi yang pernah dilakukan oleh banyak peneliti. Sehingga nantinya dapat menarik kesimpulan atas study tersebut.

Pertama studi yang dilakukan terhadap beberapa perusahaan yang bebasis syariah dapat memperlihatkan bagaimana kinerja perusahaan tersebut berjalan. Study yang dilakukan oleh Ruslan dengan mengambil study kritis aplikasi Manajemen Sumber Daya Manusia secara Syariah pada lembaga keuangan public islam, membawa pada suatu kesimpulanpertama, sumberdaya sayariah tidak hanya sebatas sebagai objek penelitian namun juga mengarah pada subjek penelitian. Kedua, peningkatan profesionalisme atau kinerja sumber daya manusia suatu perushaan juga perlu diberikan perhatian khusus dimana sumber daya tersebut juga dapat berperan sebagai agen pembawa keberkahan bagi masyarakat disekitarnya. Ketiga, mamajemen sumber daya manusia merupakan system yang bebas yang hanya mampu dimasuki oleh nilai dan norma yang sangat dinamis di suatu wilayah, sehingga perlu perhatian khusus dalam menangani hal tersebut.

Study lain juga dilakukan oleh Naafilah 2014, dalam melihat Analisis Pengaruh Etika Kerja Islam Terhadap Kepuasan Kerja, Komitmen Organisasional dan Organizational Citizenship Behavior. Analisis ini mengarah pada kesimpulan, etika kerja mempunyai pengaruh yang signifikan terhadap kepuasan kerja, etika kerja islam mempunyai pengaruh positif dan signifikan terhadap komitmen organisasional. Terakhir etika kerja Islam juga memiliki pengaruh positif dan signifikan terhadap organizational citizenship behavior. Dari penelitian tersebut, kita bias melihat bagai mana kekuatan dari pelaksanaan etika oleh agen terhadap trush masyarakat pengguna jasa ataupun barang yang diproduksi oleh perusahaan.

Hasil study yang dilakukan oleh penelitian Center for Study of Religion and Culture (CSRS) UIN Syarif Hidayatulla, menyatakan bahwa salah satu penyebab pengelolaan wakaf belum professional adalah dikarenakan adanya masalah dalam system manajemen sumbet daya manusia yang kurang terarah. Begitu juga halnya yang dilakukan oleh Ahmad Rafiki dkk, dalam pembahasan mengenai sumber daya manusia Islam dan keterkaitannya dengan performa perusahaan study kasus pada perusahaan kecil dan menengah di Bihrain. Dimana hasil penelitian tersebut menunjukan beberapa hasil analisis terkait perusahaan muslim di Bihrain dimana pengalaman, motivasi, pelatihan dan 
pembelajaran berpengaruh secara signifikan terhadap performa perusahaan.

Kajian yang dilakukan oleh $\mathrm{H}$. Syafruddin dan Efa, dalam judul Pengaruh Pemahaman Nilai- Nilai Syariah Terhadap Perilaku Bisnis Pedagang Minang Pada Pasar AUR Kuning Bukit tinggi. Menyimpulkan adanya terjadinya penambaham pemahaman terhadap nilai nilai syariah akan berdampak pada perubahan perilaku kearah yang lebih baik. Sebaliknya jika pemahaman itu nol, maka nilai prilaku menjadi negative. Nilai prilaku yang positive tersebut akan mengarahkan kita pada suatu keadaan kinerja sumber daya manusia yang lebih baik.

$\begin{array}{rrrr}\text { Sehingga } & \text { dengan uraian kasus } \\ \text { singkat yang } & \text { telah } & \text { dipaparkan, }\end{array}$ mengantarkan kita pada apa dan bagaimana seharusnya nilai etika dan moral yang dapat membantu kita dalam menjalankan aktivitas sebagai manusia. System manajeman adalah system yang terbuka atas nilai, norma dan etika. Sehingga manajemen terlahir dari kondisi masyarakat yang selalu berkembang dan berubah. Namun, pegangan Al- Quran dan Al Hadis adalah pedoman yang harus dijalankan oleh kita sebagai umatnya. Dengan berpegang pada kebermaslahatan, kita juga diharapkan mampu untuk meningkatkan performa perusahaan juga kinerja individu perusahaan.

\section{Kesimpulan}

Dunia mulai memandang perlu adanya etika dan moral dalam menjalankan bisnis sebagai upaya meminimalisisr adanya kekurangan yang menyebabkan kegagalan pasar. Sementara itu etika dan moral dalaam islam sendiri telah diatur sedemikian rupa dalam menjalankan kehidupan sebagai seorang manusia. Seperti yang diaplikasikan oleh Nabi Muhummad SAW dalam menjalankan bisnisnya sebagai seorang pedagang yang tersohor. 1)Larangan memperdagangkan barang atau jasa haram. 2) Bersikap benar, amanah dan jujur, adalah kunci keberhasilan. 3) Menegakkan keadilan dan mengharamkan bunga atau riba. 4) Menerapkan kasih saying dan mengharamkan monopoli. 5)Menegakkan toleransi dan persaudaraan.

Pelaksanaan etika dan moral islam dalam manajeman sumber daya manusia dapat membawa dampak pada peningkatan performa perusahaan. Hal ini telah banyak dibuktikan oleh berbagai penelitian yang pada intinya penerapan manajeman sumber daya manusia secara islami akan membawa pada kebaikan dunia juga kebaikan akhirat. Hal ini merupakan dampak dari konsep etika dan moral bisnis yang tidak hanya berlandaskan pada laba semata namun juga kemaslahatan bagi orang disekitarnya sehingga kepercayaan masyarakat akan meningkat seiring dengan perbaikan sumber daya manusia sebagai daya saing kompetitif dalam persaingan perusahaan.

\section{Daftar Pustaka}

Abd.Gofur, Ruslan. Manajemen Sumber Daya Manusia (MSDM) dalam Perspektif Ekonomi Syariah: Studi Kritis Aplikasi MSDM pada Lembaga Keuangan Publik Islam.IAIN. Lampung

Abu Sinn, Ibrahim. 2006. Manajemen Syariah. Jakarta: Raja Grafindo Persada.

Agustianto. 2008. Etika Bisnis dalam Islam.

Chowdhury Abdul Mannan. 2003. Human Resource development and Economic Growth: A critical analysis with special references to Banglades. Executive Views, IIUC. 2(1)

Ellitan, Lena. 2002. Praktik-Praktik Pengelolaan Sumber Daya Manusia dan KeunggulanKompetitif Berkelanjutan. Universitas Katholik Widya Mandala. Surabaya. 4(2) 
Ilhaamie Abdul Ghani Azmi. 2009. Human Capital Development and OrganizationalPerformance: A Focus on Islamic Persfektif. Syariah Jurnal. 7(2)

Isnoer Narjono, Arijo. 2013. Islam Ethics Employee Motivation. STIE Asia. Malang. $7(2)$

Karimi, Syafruddin dkk. 2013. Pengaruh Pemahaman Nilai- Nilai Syariah Terhadap Prilaku Bisnis Pedagang Minang Pada Pasar AUR Kuning Bukit Tinggi.

Lailatirohmah, Naafillah.2014. Analisis Pengaruh Etika Kerja Islam Terhadap Kepuasan Kerja, Komitmen Organisasional dan Organizational. Universitas Diponogoro. Semarang

M.Sail Rahmi dkk. Religious Education and Training in Developing Future Human ResourceProfessionals : Views From Expert and Teachers. Universitas Putra dkk. Malaysia

Mahiuddin, Golam. 2012. Human Resource Development: Banglades Perspective. Universitas Technology Malaysia.

Malaysia. 5(1)

McCormick, Donald W. 1994. Spiritual and Management, Jurnal of Manageral Psychology. Brandford. 9(2)

Muafi. 2003. Pengaruh Motivasi Spiritual Karyawan Terhadap Kinerja Religius: Studi Empiris di Kawasan Industri Rungkut Surabaya. Jurnal Siasat Bisnis. 1(1)

Nur Fadilah. Ali. 2014. Tinjauan Etika Bisnis Islam Terhadap Pengelolaan Dana Wakaf Tunai (Studi di Lembaga Wakaf dan Pertanahan NU DIY). Universitas Islam NegriSunanKalijaga. Yogyakarta Indonesia

Rafiki. Ahmad, M Alkhalifah, Buchari. Ahmad. 2014. Islamic Human Capital and Firm Performance : An Edvidence of Small and Medium Enterprise in Bahrain. Canadian Center of Science and Educati 
